Војкан Стојичић ${ }^{1}$

Милена Јовановић ${ }^{2}$

Универзитет у Београду

Филолошки факултет
УдК 371.3::811.14'06(497.11)

DOI 10.18485/zivjez.2016.36.1.13

Прегледни рад

\title{
НЕОХЕЛЕНСКЕ СТУДИЈЕ ДАНАС - ПРИЛОГ ИСТОРИЈИ УЧЕЊА ГРЧКОГ ЈЕЗИКА*
}

У раду је укратко приказан историјат учења грчког језика са кратким освртом на диглосију као проблем који је превазиђен

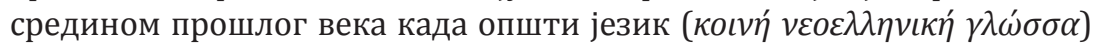
постаје званични језик Републике Грчке. Укратко су истакнута питања која се односе на истраживање наставе и учења модерног грчког језика: ко га је све и из којих разлога учио као страни, какве су биле потребе и колико је било интересовање за његово учење, у матици и дијаспори, као и који је био профил наставника. Најзад, када је реч о институционализованој настави грчког језика, два су поглавља посвећена почецима наставе грчког језика код Срба и настави модерног грчког језика на универзитетском нивоу. Посебно је истакнуто оснивање Катедре за неохеленске студије, што представља почетак универзитетске наставе модерног грчког језика у Србији.

Кључне речи: грчки језик (као страни), диглосија, настава, учење, дијаспора, Србија

\section{1. Увод}

Однос суседних језика или језика у контакту обично јесте и лингвистичко и геополитичко питање, тако да то важи и за везе грчког ${ }^{3}$ и српског језика, без обзира на то што немају

1 vojkans@hotmail.com

2 milenamjovanovic@gmail.com

* Овај рад настао је у оквиру пројекта Језици и културе у времену и простору, бр. 178002, који финансира Министарство просвете, науке и технолошког развоја Републике Србије.

3 Уобичајено је да се назив грчки језик употребљава за модерни грчки 
(више) заједничку границу, а нарочито ако се има у виду садашња геополитичка позиција балканских језика и њихова перспектива унутар јединственог европског простора. Познато је да се у бројним документима европских институција истиче потреба да се поштују и чувају све различитости па тако и језичке, како пише у Повељи о основним правима у ЕУ, и то довољно уопштено да се може схватити као начелни етички став $^{4}$. Једно од права сваког појединца у Унији, како стоји у наведеној Повељи, јесте да се може обраћати институцијама ЕУ на неком од језика који је предвиђен Уговором о ЕУ ${ }^{5}$ те да је институција обавезна да му на истом језику и одговори ${ }^{6}$ Отуда су у Уговору о ЕУ таксативно наведени језици на коме је сачињен ${ }^{7}$, што их чини равноправнима и званичнима (сва-

језик насупрот класичном грчком језику (код нас су били у употреби и називи старогрчки и новогрчки према немачком altgriechisch и neugriechisch). Појам грчки језик може бити назив за (један и јединствен) језик којим су говорили Грци у његовом целокупном трајању (као што појам грчка књижевност може обухватити и античку, хеленску, и модерну грчку књижевност). „The Union shall respect cultural, religious and linguistic diversity." (Charter of Fundamental Rights of the European Union (2016/C 202/02), Article 22 Cultural, religious and linguistic diversity, p. 398). У Пречишћеној верзији Уговора о европској унији (који потписују и нове чланице Уније), стоји: „It shall respect its rich cultural and linguistic diversity, and shall ensure that Europe's cultural heritage is safeguarded and enhanced." (Consolidated Version of the Treaty on European Union, Article 3, p. 17; Article 165, p. 120; Article 207, p. 140). Оба документа доступна на http://eur-lex.europa. eu/legal-content/EN/TXT/PDF/?uri=0J:C:2016:202:FULL\&from=EN .

5 Ово право конкретизује начелни став поштовања диверзитета у ЕУ.

6 „Every person may write to the institutions of the Union in one of the languages of the Treaties and must have an answer in the same language“ (Charter of Fundamental Rights of the European Union (2016/C 202/02), Article 41, p. 402; http://eur-lex.europa.eu/legal-content/EN/TXT/PDF/?uri=0J:C:2016:202:FULL\&from=EN)

7 This Treaty, drawn up in a single original in the Bulgarian, Croatian, Czech, Danish, Dutch, English, Estonian, Finnish, French, German, Greek, Hungarian, Irish, Italian, Latvian, Lithuanian, Maltese, Polish, Portuguese, Romanian, Slovak, Slovenian, Spanish and Swedish languages, the texts in each of these languages being equally authentic, shall be deposited in the archives of the Government of the Italian Republic, which will transmit a certified copy to each of the governments of the other signatory States. (Consolidated Version of the Treaty on European Union, Article 55, p. 45; http://eur-lex.europa.eu/ legal-content/EN/TXT/PDF/?uri=0J:C:2016:202:FULL\&from=EN) 
ка чланица Уније може преводити још на неки језик ако је то предвиђено њеним уставним поретком ${ }^{8}$ ). Данас говоримо о званична двадесет четири језика' ${ }^{9}$ чија се оправданост употребе не огледа само у цивилизацијском и културном контексту, већ и у националним и историјским оквирима.

С тим у вези стиче се утисак да су становници Старог континента последњих година схватили да познавањем само једног или два страна језика не могу бити довољно економски конкурентни, нпр. на тржишту рада, што је резултовало свешћу да треба учити најмање два, евентуално три страна језика. Међутим, противуречност између начела (о поштовању различитости) и практичне примене прокламованог изазива проблеме на свакодневном нивоу, са чиме се институције Европске уније суочавају од оснивања: таква је, нпр. обавеза да се сви документи, укључујући и све оно што прати њихову израду, усвајање и примену, преводе на све језике Уније, што доводи до преиспитивања сврсисходности институционалног превођења на толико језика, а посебно на тзв. мале ${ }^{10}$, односно,

8 This Treaty may also be translated into any other languages as determined by Member States among those which, in accordance with their constitutional order, enjoy official status in all or part of their territory. A certified copy of such translations shall be provided by the Member States concerned to be deposited in the archives of the Council. (Исто)

9 Посматрано са социолингвистичке тачке гледишта, овај релативно велики број језика, који се може повећати ако се прошири Европска унија, прагматична је и реална потреба, јер јој је циљ да усклади противуречности, да уједначи минимум заједничких услова и да установи стандарде те да на тај начин успостави равноправност међу чланицама условно речено првобитног језгра (Европска економска заједница - EE3) и свих оних које су се прикључиле или теже да се прикључе. Реч је заправо о трајном процесу стварања нових друштвених односа у једној тако разнородној заједници каква је Европска унија, поготово када се узму у обзир национални, политички (у најширем смислу) и економски фактори њених земаља-чланица, што је далеко значајније од поједностављене идеје о једнакости која се углавном своди на спречавање да се фаворизује само један језик, односно нација.

10 Разматрајући савремену језичку ситуацију, често се језици квалификују као мали или велики, најчешће према бројности говорника или, евентуално, према територијалној раширености. У том смислу социо- 
Војкан Стојичић / Милена Јовановић

језике са малим бројем говорника, у које се убраја и грчки језик (Мутавџић и Стојичић 2013).

Генерално посматрано, модерни грчки језик је познат углавном као службени језик Грчке и Кипра, који ван граница матичних држава зна и говори релативно мали број људи. Овакво стање се обично објашњава лингвистичком ситуацијом у којој су се Грци налазили више од једног века, чија је главна карактеристика била диглосија. Грци нису (били) изузетак, јер су и други народи, укључујући Србе, имали две, а неки и више од две варијанте (матерњег) језика којим су говорили и којим су се споразумевали, али који нису морали бити по дефиницији разумљиви свим припадницима исте (говорне) заједнице. Будући да су за лингвисту све језичке појаве равноправне, онда традиционална дефиниција да је важећи и исправан језик једино онај који је стандардан ${ }^{11}$, што обично значи књижевни језик, више није довољна. Грчки језик се већ својом тридесет векова старом књижевношћу одупире таквом традиционалистичком дефинисању важећег или правог, итд. језика, а још се више одупире стварном ситуацијом; одупирао се чак и онда када се десило да се један до крајности извештачен језик наметне као „природни“ језик. Диглосија наиме означава друштвену ситуацију

лингвисти на макролингвистичком плану говоре о две групе језика које се налазе у међусобно несразмерном односу: са једне стране су (многобројни) мали језици (minority languages), а са друге (малобројни) велики језици (mayority languages). Сматра се да 96\% човечанства користи између 260 и 280 језика, што је тек 4\% од укупног броја свих постојећих језика на свету (између 6000-7000). Од тог броја, свега дванаест језика (или $0,2 \%$ ) има најширу употребу у свету. Класификација заснована на принципу бројности језика, у односу на бројност њихових (нативних) говорника појављује се у радовима многих научника већ неколико деценија. Тако класификован грчки језик припада групи великих језика, али не и групи великих светских. Исто би се могло рећи за српски. Ипак, како се показало, критеријум (пропорционалне) бројности не може бити довољан, осим у датом тренутку пребројавања (нативних) говорника, поготово ако се уведу параметри које је тешко квантификовати, као што је улога језика у активностима као што су наука, уметност, дипломатија, затим религија или узајамни утицаји два или више језика, итд. (Стојичић и др. 2011).

11 Могао би се назвати и школским, јер се формално и учи у школи. 
унутар једне исте друштвене заједнице, у којој се један језик говори на два (или више) начина, од којих сваки има своју намену, сврху или циљ, с тим што немају исти друштвени положај, пре свега у образовном систему, тако да један од њих обично постане инфериоран у културном погледу због супремације оног другог. У том смислу грчку диглосију карактеришу катаревуса

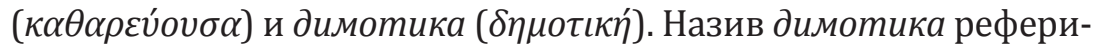
ра на простонародни говор, дакле „инфериоран“, а који никако не треба сводити на говор „простог народа“, док је катаревуса била традиционално сматрана језиком којим су говорили стари Грци, дакле „супериорна“ и једино прихватљива у институцијама као службени језик школе, цркве и администрације.

Другим речима, катаревуса је била идиом „вишег“ реда, којом се једино могао достигнути „високи“ стил, док је димотика - као говорни идиом обележена, зависно од територије, дијалекатским и другим језичким особеностима - била прихватљива (само) за свакодневну употребу. Али, уколико је инфериоран онај језик којим већина „по природи“ говори, а намеће се онај „мањински“, којим „треба“ говорити, онда може доћи до кризе и конфронтације присталица супротстављених језика. То није сукоб „говорника“ једног и „говорника“ неког другог, различитог језика, него је предмет сукобљавања питање „за или против“ књижевног (службеног или званичног у најширем смислу) језика. Такво питање је неизоставно од интереса за целу заједницу, која обично говори мање-више исто, а може се свести на прописивање којим ће се језиком писати (Јовановић 2014: 44).

Историја грчког језика ни у ком случају није непрекинута равна линија мерена вековима. Напротив, ако је упоредимо са реком, она не само што има притока и рукаваца, богатијих водом или сасвим плитких, краћих и дужих, него је било и периода када се све стицало у један општи или заједнички језик, $\eta$ коเvи́ $\delta \iota \alpha ́ \lambda \varepsilon \kappa \tau о \varsigma$, или посрбљено којна, од којих треба поменути хомерску, хеленистичку или новозаветну, и напослетку савремену. При том не треба занемарити то да се дешавало да се та река раздвајала и после неког времена спајала - то су биле диглосије, некада ограничене на уски круг говорника, а некада такве да 
су изазивале кризе у друштвеним односима. Најбурнија је била

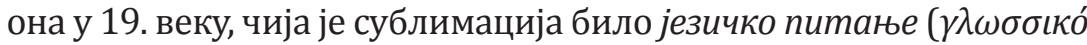

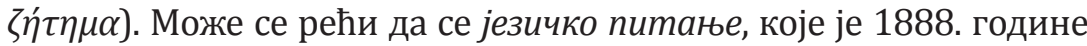
ескалирало због познатог Психарисовог путописа Моје путовање (Тo $\tau \alpha \xi i \delta \iota \mu о v)$, решавало практично све до 1976. године, када је по природи ствари димотика превладала. То је био дуготрајан процес са много, углавном неуспешних покушаја, да се димотика наметне, али који су мало по мало нагризали традиционалистички установљени систем. Под притиском јавности димотика је 1917. године први пут уведена у образовни процес (одлуком Венизелосове владе ${ }^{12}$ ). Таквих је покушаја било неколико, све док није увођењем монотонске акцентуације општи језик (коıvи́

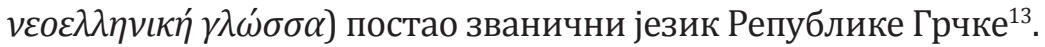

\section{2. Учење модерног грчког језика у Грчкој и свету}

Имајући у виду комплексну лингвистичку ситуацију, која се дефинитивно разрешила коначним решењем језичког пи-

12 Више о овоме в. Мутавџић и Камбурис 2014: 509-526.

13 Модерни, нови или савремени грчки језик добио је 1976. године статус службеног језика Републике Грчке тек након великих и некада бурних политичких промена:

- $\quad$ Период од 1917-1920;

- $\quad$ Период од 1922-1925;

- $\quad$ Година 1930. кад је као министар просвете, Јоргос Папандреу „издејствовао“ изгласавање Закона бр. 5045, којим се димотика уводи у прва четири разреда основне школе, док би у 5. и 6. разреду настава текла паралелно са катаревусом;

- $\quad$ За време владе Јоаниса Метаксаса, велики грчки лингвиста Манолис Тријандафилидис добио је „задатак“ да састави граматику модерног грчког језика;

- $\quad$ Година 1964. када се Папандерусова влада поново позабавила увођењем димотике у школе, уз помоћ „Папануцосове реформе“. Покушај је пропао 1965. године;

- $\quad$ Година 1976. је најбитнија година у новијој грчкој историји, барем када је реч о систему образовања. Законом бр. 309, донетим исте године, министар просвете Георгиос Ралис потписао је одлуку којом је димотика (или општи језик, како се уобичајено назива) постала званични језик образовања. 
тања, односно формалним укидањем политонске акцентуације, може се претпоставити да је то тренутак када се широм отварају врата заинтересованима да уче грчки језик. Учио се, дакле, грчки и пре тога, постојале су школе у Грчкој у оквиру образовног система, као што су постојале грчке школе ван грчког говорног подручја, али питања наставе и наставних метода била су потиснута у други план зато што је у првом плану била борба за народни језик, због чега су и истраживања модерног грчког језика углавном фокусирана на историјат учења грчког језика, а не на саму наставу и наставне методе учења грчког као страног језика. У другој половини 20. века грчки језик као страни институционализовано се учио углавном на катедрама за класичну филологију на европским, америчким и аустралијским универзитетима. Други вид учења грчког језика одвијао се ван образовних институција, у исељеничким „клубовима“14, где је по свој прилици била организована и настава грчког као матерњег језика, на сличан начин како се то и данас ради ${ }^{15}$.

14 Имајући у виду да су миграторна кретања Грка била велика, било је природно да се исељеници из матице окупљају, чувајући на тај начин језик и обичаје, надајући се да ће се ипак једног дана вратити на неку своју Итаку.

15 Овде се не мисли на неку врсту званичне помоћи Републике Грчке, односно надлежног Министарства просвете, образовања и верских питања, каква је данас и више него присутна. Грчка дијаспора, без обзира на то да ли је реч о емигрантима или о Грцима који су стицајем геополитичких прилика остали ван матице, увек је водила рачуна о очувању грчког језика, националне културе и обичаја. Може се претпоставити да су се Грци, поготово емигранти, сами организовали, како би им деца што дуже остала у контакту са језиком. Данас је ситуација потпуно другачија у систему институционализоване наставе модерног грчког језика као матерњег језика ван матице. Надлежно министарство расписује конкурс за ангажовање учитеља који би службовали у страној земљи у којој су организоване „грчке школе“, односно школе у којима се настава одвија по плану и програму Министарства просвете Републике Грчке. Реч је, углавном, о некој врсти „додатне“ школе (у највећем броју случајева), али не треба запоставити ни чињеницу да у Европи (Немачка, Аустрија и сл.) постоје основне школе и гимназије у којима се настава из готово свих предмета у потпуности одржава на 
Почетком шездесетих година, како Андонопулу (2000: 67) наводи, све већи број страних студената долази у Грчку ради студија, те са њиховим доласком расте и потреба за организовањем часова грчког језика као страног. Како је познавање грчког језика било предвиђено као услов за упис основних академских студија на Аристотеловом универзитету у Тесалоники, Школа за новогрчки језик ${ }^{16}$ Филозофског факултета на овом универзитету почиње да прима прве (стране) студенте 1970. године ${ }^{17}$. Из године у годину све је већи број студената неохеленистике из целог света, који као стипендисти долазе на Аристотелов универзитет, како би унапредили своје познавање грчког језика ${ }^{18}$.

грчком језику. Ове школе се делом финансирају из буџета Републике Грчке, а делом из буџета ЕУ. Таква „додатна“ школа постоји и у Београду, где наставу у прва четири разреда основне школе прати велики број младих Грка, било да је реч о деци пословних људи из Грчке, деци дипломата или деци из мешовитих бракова. Настава се организује под покровитељством Амбасаде Републике Грчке у Београду већ дуги низ година, у ОШ „Скадарлија“.

16 У Школи се организују часови грчког језика и цивилизације за одрасле, било да су они странци, било да су Грци из дијаспоре. Највећи број њих има заједнички циљ - да науче модерни грчки језик како би се успешно „уклопили“ у грчки систем високог образовања.

17 Године 1970. се није још увек могло говорити о акредитованим студијским програмима на другим страним језицима, који, како се чини, у данашње време заузимају све битније место у универзитетским курикулумима, поред оних који се тичу студија на даљину.

18 Како Александри и Капуркациду наводе, да би неко могао пратити наставу модерног грчког језика у оквиру неког од понуђених курсева, мора поседовати макар диплому средње школе и мора имати регулисан свој боравак у Републици Грчкој (Александри и Капуркациду 2012: 632). Последњих неколико година, поред организације часова модерног грчког језика, лектори који су ангажовани у настави организују велики број ваннаставних активности, како би странцима пружили увид и у неке елементе грчког друштва које није могуће увидети учењем језика на часу. Једну од новина представљају и часови кувања, где странци могу поред вокабулара у вези са храном, сазнати и за неке друге, посматрано из културолошког аспекта, специфичне елементе грчке културе. Поред организације наставе, Школа настоји да својим деловањем изађе у сусрет и странцима, који предају модерни грчки језик у некој другој институцији, било у Грчкој, било у иностранству. С тим 
На Институту за балканолошке студије у Тесалоники ${ }^{19}$, који је основан 1953. године, часови модерног грчког језика одржавају се од 1974. године. Од тада, па до данас, више хиљада стипендиста Министарства културе и туризма похађало је Летњи програм грчког језика и цивилизације овог Института. У поређењу са програмима наставе других институција из исте области, може се рећи да је програм Летње школе грчког језика и цивилизације неупоредиво разрађенији, имајући у виду да се настава, све до почетка светске економске кризе, организовала у чак дванаест нивоа, што ниједној другој институцији није пошло за руком до данас ${ }^{20}$.

Када је реч о институционализованој настави модерног грчког као страног на Атинском универзитету, у литератури је могуће пронаћи више различитих података. Андонопулу (2000: 67), позивајући се на Службени гласник Владе Републике Грчке, наводи да се 1975. године почело са организованом наставом и то у оквиру Центра за стране језике. У историјату Школе за грчки језик Филозофског факултета Националног и Каподистријског универзитета у Атини наводи се податак да је Центар за стране језике основан 1950. године. Паралелно са наставом страних језика организовани су и први часови грчког језика као страног, углавном за стране студенте и чланове дипломатских мисија на служби у Атини. Године 1991. основан

у вези, организују се семинари за стручно усавршавање предавача модерног грчког као страног, што је од изузетне користи за лекторе који предају језик на неком универзитету у иностранству. Школа за новогрчки језик званични је испитни центар за проверу знања грчког јези-

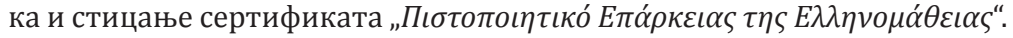

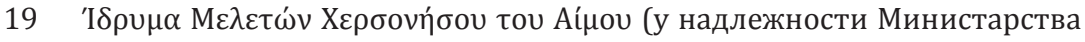
културе и туризма).

20 Овде треба истаћи допринос професора Констандиноса Димадиса, који је као управник Међународног програма за учење савременог грчког језика као страног учинио много да овај програм стекне, може се рећи, светску славу. Пажљивим одабиром дидактичког материјала, пратећи савремене тенденције у настави страних језика, и, можда најважније, посебном селекцијом наставног особља, професор Димадис, председник Европске асоцијације за неохеленске студије, поставио је високе стандарде када је реч о предавању савременог грчког језика као страног. 
Војкан Стојичић / Милена Јовановић

је Међукатедарски програм за учење грчког језика као страног, да би 1994. године била основана Школа за грчки језик ${ }^{21}$, као самостална организациона јединица.

Поред ове три институције, готово у исто време, часови модерног грчког као страног организују се на Ваздухопловној академији у Атини, на Војној академији, на курсевима за стра-

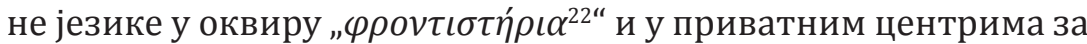
стране језике (Андонопулу 2000: 67). Никако не треба умањити значај ни других школа за грчки језик, које делују при универзитетским центрима, у Комотинију, на Крфу, на Родосу, у Волосу, на Криту, као и на Кипру.

У данашње време најзначајнија је помоћ коју пружа Министарство просвете, образовања и верских питања ${ }^{23}$ Републике Грчке у промоцији и дисеминацији грчког језика. У оквиру овог Министарства делује и Центар за грчки језик у Тесалоники, који постоји од 1994. године, као саставна јединица Министарства просвете Републике Грчке ${ }^{24}$.

21 Имајући у виду да је реч о највећој и најстаријој Школи за модерни грчки језик као страни при неком од универзитета у Републици Грчкој, треба истаћи да је велики број студената неохеленистике у Београду имао прилику да у њој прати наставу. У односу на остале програме за усавршавање модерног грчког као страног, планом и програмом ове школе предвиђено је да настава на Летњем курсу грчког језика $(\Theta Y E \Sigma \Pi A)$ траје 6 недеља, дакле дуже него на било којој другој установи. Поред наставе језика, студенти су у прилици да прате и часове историје, али и да одлазе на једнодневне излете како би посетили велики број археолошких локалитета. Школа за грчки језик организује и полагање испита за стицање сертификата о знању грчког језика два пута годишње.

22 Нешто попут института̂ за стране језике.

23 Како су друштвене прилике и политичка ситуација у Републици Грчког последњих шест година доводиле до већег броја ванредних парламентарних избора, тако се и назив Министарства просвете мењао више пута. У овом прилогу назив је Министарство просвете, (нацио-

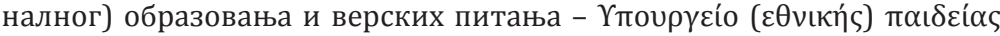

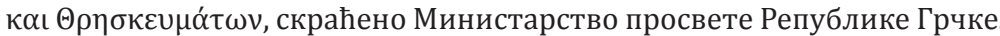

24 Са своје четири организационе јединице које чине Департман за лексикологију, Департман за лингвистику, Департман за подршку и ширење грчког језика као и Департман за језик и књижевност, Центар настоји да одговори на све потребе савременог друштва, које се тичу 
Када је реч о институцијама у којима се учи грчки језик у свету, не може се говорити о прецизним подацима. Иако Министарство просвете Републике Грчке настоји да последњих година покрене платформу која би „повезала“ све институције у свету, које се баве наставом грчког као страног, ипак се није много одмакло од основне замисли. Такође, на интернет презентацији Центра за грчки језик у Тесалоники могуће је пронаћи податке о званичним испитним центрима за проверу знања грчког језика и стицању Сертификата о познавању

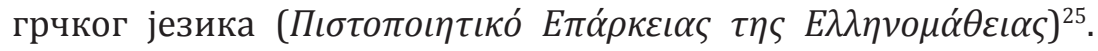
Оно о чему се може поуздано говорити јесте да се настава грчког језика данас одвија у образовним институцијама на свим континентима ${ }^{26}$. Највећа активност, могло би се условно рећи, забележена је у Сједињеним Америчким Државама, као и у Аустралији, имајући у виду да се велики број Грка, напуштајући матицу, населио управо у овим државама. Активности које бележе Америчка асоцијација за неохеленске студије, односно Аустралијска асоцијација за неохеленске студије недвосмислено

грчког језика и књижевности. Велики је број активности које се везују за овај Центар. Поред научних истраживања у области грчког језика и књижевности, језичког образовања и језичких политика̂, сертификације знања грчког као страног, издавачке делатности, која се односи како на грчки као матерњи, тако и на грчки као страни језик, једна од основних мисија Центра јесте пружање перманентне подршке свим оним институцијама, које се баве грчким језиком као страним било у земљи, било у иностранству. Треба имати у виду и чињеницу да је Катедра за неохеленске студије дуги низ година била званични испитни центар за проверу знања грчког језика, дакле испитни центар који је акредитовала државна институција Министарства просвете Републике Грчке, много година пре него што ће се у високом образовању у Срба говорити о примени начела Болоњске декларације.

25 Више о овоме в. на http://www.greeklanguage.gr/greekLang/modern_ greek/foreign/guides/tuition/show.html?group=2.

26 Од помоћи би могао бити податак о образовним институцијама којима је финансијски помагала Фондација Александроса Оназиса (http:// www.onassis.org/uploaded/pdf/Awards ). Такође, од користи могу бити и подаци Генералног секретаријата за питања Грка у иностранству (http://www.ggae.gr/frontoffice/portal.asp?cpage=NODE\&cnode=12), као и Министарства просвете Републике Грчке (http://www.yppo. gr/1/g1540.jsp?obj_id=2712). 
Војкан Стојичић / Милена Јовановић

указују о постојању великог броја оних који се баве неохеленским студијама. С тим у вези, треба поменути и пет конгреса Европске ${ }^{27}$ асоцијације за неохеленске студије, организованих од 1995. године до данас, на којима је учествовао велики број угледних лингвиста и филолога из целог света.

Поред ових, истичемо и активности Хеленског фонда за културу и његових шест испостава ${ }^{28}$, који поред културних дешавања организује и часове грчког језика, према начелима 3EOJ-a. У исто време, ова представништва имају и улогу испитних центара за проверу знања грчког језика „Елиноматија“.

\section{3. Модерни грчки међу балканским језицима}

Уколико се посматра балканска историја, у одређеним периодима приметно је „надметање“ међу балканским језицима. Некада је оно било у блиској вези са непосредним ширењем балканских народа, тј. њиховим територијалним претензијама. Ако изузмемо Грке, који су више од једног миленијума били водећа нација у читавој Југоисточној Европи, дешавало се да су у појединим периодима балканске историје два, или чак три језика у истом тренутку тежила да постану примарни језици комуникације ${ }^{29}$ (Мутавџић и Стојичић 2013: 675).

Учење страних језика данас представља реалну потребу и суштину опстанка, нарочито ако узмемо у обзир сложене

27 Катедре за неохеленске студије широм Европе последњих година суочавају се са све већим проблемима. Због недостатка финансијских средстава, на многим европским универзитетима дошло је до смањења броја студената неохеленистике. Неки угледни универзитети који имају вишедеценијску традицију у промоцији грчког језика и књижевности престали су да уписују нове студенте. Међутим, Катедре за неохеленске студије у Србији, Бугарској и Русији успевају да одрже константан број студената у последњих десет година.

28 Реч је о представништвима у Београду, Букурешту, Софији, Трсту, Мелбурну и Тирани.

29 Овде мислимо на ширење српске државе под Душаном Силним, када су и српски и грчки били службени језици (упор. Мутавџић и Стојичић 2013: 673-679). 
процесе економске глобализације и брзу индустријску револуцију. Како Мутавџић и Камбурис (2014) наглашавају, између Европске уније и Балканског полуострва постоји велика разлика кад је реч о значају учења грчког језика у страним срединама, узимајући посебно у обзир чињеницу да су за Грчку од посебног значаја земље у њеном непосредном географском окружењу - како оне на Балкану, тако и у Југоисточној Европи ${ }^{30}$ - у којима је грчки језик био суштински носилац културе и религије готово до краја 19. века.

Географска близина, религијски фактор, вишевековна историјска повезаност, као и јасна спољнополитичка активност допринеће, између осталог, да се грчки језик учи све више на Балкану. Надлежне институције Републике Грчке последњих година покренуле су низ пројеката ${ }^{31}$, који су омогућили становницима балканских држава учење овог језика ${ }^{32}$.

Са друге стране, колико год да су напори надлежних институција Републике Грчке допринели промоцији и ширењу грчког језика, досадашња пракса је ипак показала да свако балканско друштво различито вреднује и посматра суседне балканске језике (и њихове народе). Ово се, пре свега, огледа у

30 Пре свих Украјина, Русија, Јерменија и Грузија. У овим земљама постоје Катедре за неохеленске студије на којима је могуће студирати грчки језик и књижевност на универзитетском нивоу. Имајући у виду величину појединих земаља, грчки језик је могуће учити на више универзитетских центара (Русија, Украјина).

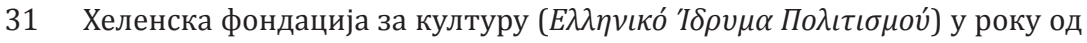
две године отворила је своје „центре“ у Букурешту, Београду, Софији, Тирани и Трсту.

32 Министарство просвете Републике Грчке, Државна фондација за стипендије ИКИ, Фондација Александроса Оназиса, Фондација Елени и Косте Уранис и Институт за балканолошке студије у Тесалоники само су неке од институција, односно фондација које последњих десет година обезбеђују стипендије за студенте основних, мастер и докторских студија на Катедри за неохеленске студије. Курсеве грчког језика у оквиру летњих програма учења грчког језика на Аристотеловом Универзитету у Тесалоники, Националном и Каподистријском универзитету у Атини, Универзитету у Јањини као и на Критском универзитету похађало је више од 350 студената неохеленистике последњих неколико година. 
Војкан Стојичић / Милена Јовановић

чињеници да балкански језици нису у истој мери заступљени у универзитетским центрима Републике Грчке, што практично значи да су се на делу показале и друштвена утрошивост и рационализација свих ресурса ${ }^{33}$.

\section{4. Почеци наставе грчког језика код Срба}

Историјат усвајања страних језика код Срба значи заправо историјат наставе и учења латинског и грчког језика, касније названих „класични језици“34 и њихових књижевности, хеленске и римске. Исти приступ је важио и за српски језик и српску књижевност ${ }^{35}$ - српски језик и српска књижевност учили су се као латински језик и римска књижевност. Овај је принцип номинално важио у 18. и добрим делом у 19. веку, пре свега зато што је латински био језик комуникације, тачније, административни језик и језик школе у Хабзбуршкој монархији ${ }^{36}$ и потом у Аустро-Угарској ${ }^{37}$. Како Јовановић истиче, „у Србији класични

33 На пример, на Филозофском факултету Аристотеловог универзитета у Тесалоники могуће је студирати само пет европских језика, међу којима нема балканских. Слична ситуација се може приметити и на Националном и Каподистријском универзитету у Атини, на Универзитету у Јањини, Демокритовом универзитету у Тракији, Егејском универзитету, Критском универзитету и сл.

34 Класични језици обухватају старе језике, којима се више не говори, али који су са различитих разлога важни за савремене језике (било за филолошка, лингвистичка и друга истраживања или, конкретно грчки и латински, за терминологију и терминографију).

35 Друга половина 19. века јесте време нормирања српског језика и развоја српске књижевности, уз ослобађање од сувише директних „школских утицаја“.

36 За развој српских гимназија у Хабзбуршкој монархији изузетно је био важан Ratio educationis из 1777. и 1806. године, јер им је послужио и као узор и као основа школских програма.

37 Реформа школства, изведена 1849. године Организационим нацртом, увела је предметну наставу у школе и, што је најважније, наставу и уџбенике на матерњим језицима народа који су у њој живели. Срби су тек у последњој четвртини 19. века коначно увели српски језик као наставни - проблем су били уџбеници којих није било на српском (упор. Јовановић 2011: 50-51). 
језици почињу да добијају значај који им припада тек са ослобођењем од туркократије, у почетку посредно, под утицајем образованих људи из Војводине и других крајева, а касније све интензивније када се ствара неопходан имућни слој образованих Срба, који постају носиоци напретка не само економског, него и културног“ (Јовановић 2011: 18).

Како културни развитак понајвише зависи од образовања $^{38}$, читање класика у оригиналу, превођење на српски и списатељски рад према античким узорима обогатили су и унапредили и са̂м српски језик, тако да је класична филологија током 19. века битно утицала на образовање, књижевност и културу Срба у Војводини, а посредно и у Србији (Јовановић 2011: 8-9).

Имајући у виду да су грчки језик и књижевност континуирано присутни у српској просвети и култури, за грчки језик могло би се рећи да је први светски језик којим су се Срби служили ${ }^{39}$. Ипак, задржао се исти принцип и онда када су грчки и поготово латински изгубили позицију базичног и обимом најважнијег предмета ${ }^{40}$, поставши класични језици који се уче као и сваки други предмет ${ }^{41}$.

38 Оно се све до 19. века темељило на књижевности која се није могла замислити без класичних аутора као узора у сваком погледу, на првом месту моралних и естетских.

39 Из овог разлога Ристовић наглашава да „ова цивилизаторско-просветитељска димензија грчког језика за стару српску просвету и културу има занимљиву паралелу у обновљеној српској држави у чињеници да је први страни језик уведен у наставни програм прве гимназије, у Крагујевцу, био грчки; штавише, да је први уџбеник написан за њене потребе био Грчка читаоница Вукашина Радишића из 1837. године“ (Ристовић 2011: 12).

40 Иако се уводе нови предмети, иако се смањује фонд часова класичних језика, они ипак доминирају. Нови захтеви времена, особито крајем века, изазивају сучељавања мишљења присталица класичне и присталица реалне наставе, али то није битно утицало на школски систем који је прописивала држава.

41 Таква епохална промена омогућила је да се уче и други, савремени, језици, без обзира на методе и исходе учења. Страни језици су се у школама учили традиционално, што је значило по моделу класичних језика: граматичка правила и примери из књижевности. С тим у 
Грци су у 18. веку оснивали своје, грчке школе у градовима $^{42}$. С обзиром на то да су учитељи у одређеној мери знали и српски језик, дешавало се да Срби своју децу уписују управо у њих, а тамо где их није било, школска управа би их ангажовала, у зависности од финансијских могућности и „оправданости“ потреба. У време митрополита Вићентија Јовановића ${ }^{43}$, у карловачкој латинској школи се, поред латинског, учио и грчки језик. У време митрополита Павла Ненадовића, поред малих и славенско-граматичких школа, ради и псалтирска славенско-грчка школа, у којој се учило појање, а у вишим разредима нешто грчке граматике ${ }^{44}$.

Грчки језик имао је у Хабзбуршкој монархији другачији положај него латински. Ratio educationis из 1777. и 1806. године

вези, Јовановић у својој студији разматра положај класичног грчког језика у савременој високошколској настави. Ауторка сматра да „ако се више не поставља питање учимо ли страни језик, него како да говоримо страни језик, где је учење само инструмент трансфера, онда би се учење не-живих језика могло поставити слично, дакле не како научити класични грчки језик, него како применити оно што схватамо и разумемо као класични грчки језик (којим се при том не говори). Реч је о практичној употреби знања о језику стечених учењем класичног грчког као језика струке, у најширем смислу те речи. То би значило да је класични грчки језик идеалан као фундамент, јер садржи углавном све (језичке) струке у сублимном стању. Преостаје само „ситница“: којом методом извршити трансфер знања. Ако се остали језици, па чак и матерњи заснивају на потреби обостране комуникације, онда треба искористити неке од елемената комуникативне методе, оних елемената који се сматрају потребним у настави класичних језика“ (Јовановић 2012: 382-383).

42 Грчке школе су постојале у Вршцу (од 1594), Темишвару (од 1606), Коморану (од 1648) итд.

43 Иначе, митрополит Јовановић је много пажње посвећивао школству у Срба, па је 1731. године била уведена у Београду школа за црквено појање. Из овог разлога са Свете Горе доведен је „искусни псалт“, јеромонах Анатолије, који је отворио и грчку школу (Ћоровић 2004: 480).

44 На основу „извештаја“ Георгија Спиде, школа је радила две године, $1755 / 56$. и $1757 / 58$. Његови извештаји о напредовању сваког ученика личе на оно што у данашње време називамо „портфолиом“. Сваког месеца бележило се колико је ученик напредовао, да ли је и у којој мери савладао читање и сл. 
предвиђао је две године филозофије или лицеја. Ту се предавао и грчки језик, поред других предмета, а сходно упутствима која је пружао Ratio educationis, настава грчког језика није била редовна, већ факултативна ${ }^{45}$.

Грчки језик се учио у Карловачкој гимназији, у вишим разредима, само школске 1817/8. године, а у Новосадској гимназији од школске 1823/1824. до 7.11.1826. године. У Новом Саду је радила и Грчка школа. Иако је била грчка, учитељи су говорили са ученицима српски, јер су углавном српска деца похађала ову школу, а нису знала грчки. Тако нешто није представљало новину, посебно имајући у виду да вера није представљала препреку. Штавише, знање грчког језика је био и више него пожељно, ако се узму у обзир трговачке и друге везе које су Срби имали са Грцима. Грчких школа је било и у Србији (у Земуну још средином 18. века, касније у Београду, Шапцу, Неготину итд.), а грчки се учио и у Лицеју у Крагујевцу. О томе како се грчки језик учио податке донекле могу пружити сачувани приручници из каснијег периода, штампани у тадашњој Србији. Они углавном садрже правила за читање, боље рећи срицање, и тематске целине разговора у различитим приликама у служби усвајања готових говорних конструкција, које би се могле користити у реалним комуникативним ситуацијама: устајање, умивање, обедовање у кући, кафани и сл. ${ }^{46}$.

Година 1849. значи велику промену у систему образовања. За Србе, гимназије остају једине „високе“ школе, јер мањинама универзитет није био дозвољен (Србима свакако не). Органи-

45 У овом периоду још увек није била успостављена онаква веза између грчког и латинског језика, каква ће се касније успоставити, када та два језика буду чинила целину, одвојену од других предмета. Та два језика после реформе 1849, као не-говорни, класични језици, постаће основа класичне наставе (Јовановић 2011: 120).

46 Поред ових тема, у приручницима су се налазиле кратке приче или анегдоте, десет божјих заповести итд. Речи су биле разврставане по „категоријама“, а језик се учио без икаквих граматичких правила. Јасно је да су ограничене потребе могле бити задовољене таквим „минималистичким“ приступом - једно друго условљава и задовољава. Уџбеници грчког, као и латинског, били су немачки. 
зационим нащртом из 1849. године у Карловачку гимназију уведен је грчки језик као редовни предмет. Латински неће више бити главни предмет, већ постаје „само“ један од предмета у курикулуму. Ова два језика представљаће основу класичне наставе, чији је главни задатак темељно познавање античког наслеђа и европских културних утицаја.

Након 1849. године, основни циљ школовања постаје стицање темељног образовања ${ }^{47}$, а латински језик више нема оно место које је имао ${ }^{48}$. Грчки језик уведен је у Карловачку гимназију школске 1851/1852, а у Новосадску следеће године. Учио се од трећег разреда у обе гимназије, али је у Новосадској укинут 1858. у корист мађарског, све до 1867. године када се уводи од петог разреда, с обзиром на то да је гимназија постала осморазредна као Карловачка. Наставни програм предвиђао је учење речи напамет, превођење са грчког на немачки и српски и обратно, а Езопове басне служиле су као штиво ${ }^{49}$.

Како је већ речено, са реформом гимназије мењају се планови и програми свих предмета, укључујући и латински језик ${ }^{50}$. Промене у програмима су се огледале не толико у распореду граматике, колико у примерима реченица и текстова. То

47 Како би настава била што сврсисходнија, било је неопходно преиспитати оправданост „већег“ или „мањег“ значаја појединих предмета, односно направити такав курикулум који би на подједнак начин „третирао“ већину предмета. Ово је било неопходно зато што су латински језик и класични аутори заузимали централно место у курикулуму и били окосница вишег образовања.

48 Како више није имао функцију језика комуникације, престала је и потреба за функцијом наставног језика, те је своје место уступио националним језицима.

49 У Карловачкој гимназији су се читали грчки аутори у оригиналу. Реч је о делима Хомера, Ксенофонта, Херодота, Платона, Демостена, Софокла. У Новосадској гимназији се нису читала Софоклова дела, а Демостенова су се читала само неколико година. Њима се може прикључити и Езоп, чије су се басне обично читале из читанки (упор. Јовановић 2011: 18).

50 Класични језици постају целина и њихово изучавање постаје оно што чини основу класичне наставе. Као класични језици они губе првобитну функцију језика комуникације, а часови постају једино место где се ови језици упражњавају и то на исти начин као и остали предмети. 
је утицало да се промене и уџбеници ${ }^{51}$. Нова концепција класичних језика остаје непромењена током друге половине 19. века, односно до I светског рата, јер ни наставни систем није мењао свој облик.

У другој половини 19. века, класични филолози потпомажу стварање норме српског језика, јер се учење грчког и латинског језика није могло замислити без познавања српске граматике. Организациони нацрт је, наиме, прописивао да се настава држи на матерњем језику, чему су највише могли допринети класични филолози већ тиме што су имали највећи фонд часова. Уџбеници су такође морали бити на матерњем језику. Научна терминологија се морала тек стварати, тако да је комбинација доброг познавања класичних и сопственог језика у личностима професора класичних језика давала најбоље резултате ${ }^{52}$.

Латински и „старогрчки“, са припадајућим им књижевностима, постају предмет класичне филологије. Под новим називом „класични језици“, постају језици наука, уметности и терминологије. Како се налазе у основи савремених националних језика уз изразиту продуктивност у стварању интернационализама у свим областима друштва, заслужено су добили једно ново, незаобилазно место у европској култури ${ }^{53}$.

\section{5. Настава модерног грчког језика у Србији}

Када говоримо о настави модерног грчког језика у Србији, традиција у његовом изучавању није ни изблиза велика као традиција у учењу класичних језика на Универзитету у Београду. Међутим, увођење неохеленских студија на Фило-

51 Просветне власти су прописивале све уџбенике и приручнике, који су били засновани на програмима.

52 Глигорије Лазић је то сажео у констатацију да је „нама Србима, одн. нашој српској књижевности, језик грчки много потребнији него латински“.

53 Поред те прагматичне функције, грчки и латински са својим књижевностима задржавају и даље посебно место у изучавању књижевности на свим нивоима. 
лошком факултету Универзитета у Београду представља веома важан чинилац развоја филолошких наука у нашој средини, израз свести о потреби да се језик и књижевност нама блиског грчког народа проучавају и на тој основи успостављају што интензивнији односи између Србије и Грчке.

Свест о тој потреби подразумевала је образложење захтева за оснивање Kameдре за неохеленске студије на Филолошком факултету Универзитета у Београду. Тај захтев, који су осмислили проф. др Јован Деретић, проф. др Дарко Танасковић и проф. др Радојица Јовићевић, заслужује да буде сачуван као документ од посебне важности. Из тог разлога, овде ће бити наведен интегрални текст тога образложења:

У својој развојној политици, Филолошки факултет од свог оснивања тежио је да прошири спектар филологија које се на њему изучавају и у томе је до сада постигао значајне резултате. Имајући у виду такву оријентацију, слободни смо да предложимо да се предузму потребни кораци за увођење неохеленских студија у наставни план и у програм научно-истраживачког рада Филолошког факултета.

Грчки језик, којим говори народ пријатељске нам Грчке и Грци расути широм света, настао је у процесу развоја најстаријег културног језика Европе, старогрчког или хеленског. Хеленске студије узете најшире обухватају стари или хеленски, средњи (византијски) и савремени грчки језик. Новогрчки језик повезан је с ранијом традицијом на двоструки начин, преко народног језика (димотика), који се природним путем развио из старогрчког и преко ученог језика (катаревуса), ослоњеног на књижевно наслеђе древне Хеладе и Византије.

Неохеленске студије обухватају језик и културу треће етапе у развоју хеленске цивилизације која је дала огроман допринос свим областима материјалне и духовне културе. На новогрчком је створена богата књижевност чији почеци сежу до 11. века. Књижевност обновљене Грчке у 19. и 20. веку дала је плејаду великих песника, међу којима и два добитника Нобелове награде (J. Сеферис, О. Елитис), као и низ сјајних прозних писаца.

Грчки језик и хеленска култура одиграли су несумњиву улогу у културној историји српског народа. Традиција стваралачких 
додира Срба и других јужнословенских народа са грчким светом почела је од досељења наших предака на Балкан и није престајала до наших дана, што се испољило у разним областима културног живота, у стварању првог нашег књижевног језика и најраније писане књижевности (рад Ћирила и Методија и каснији непрекидни утицаји Византије на нашу стару културу), у народној поезији, у развоју српског језика, у културним везама наших писаца новијег времена са Грчком.

Значајно је, такође, да рещепщија духовног наслеђа античке Грчке код нас није ишла само посредно, преко Запада, него и непосредно, преко сталних културних додира нашег народа с Грцима. Византијска и неохеленска цивилизација чине окосницу како српско-грчких узајамности, тако и балканолошких студија у свим областима, у историји, језику, религији, књижевности, уметности, народној култури. Без новогрчког не може се изучавати новија историја и култура балканских народа.

На Филолошком факултету и у Србији проучавају се на универзитетском нивоу сви језици суседних народа и народа с којима смо непосредно комуницирали у разним периодима наше историје. Једино је новогрчки неоправдано остао по страни. Оснивањем Катедре за неохеленске студије отклонила би се та аномалија и испунила осетна празнина у нашој филологији. Сматрамо да се Београд афирмисао у 20. веку као значајан центар за класичне хеленске студије, а постоје сви услови да то постане и за неохеленско наслеђе.

Наставно-научно веће Филолошког факултета Универзитета у Београду прихватило је ово образложење и на основу тога је 30. јуна 1993. године донело одлуку на основу које се оснива Катедра за неохеленске студије, а у оквиру ње и Група за новогрчки језик и књижевност, под редним бројем 28. Наставни план и програм ове студијске групе Наставно-научно веће утврдило је на својој седници од 11. маја 1994. године. Наставно-научно веће Универзитета у Београду на својој седници од 07. новембра 1994. године потврдило је одлуку о оснивању Катедре за неохеленске студије, на основу захтева Филолошког факултета од 19. маја 1994, а предлог о оснивању је образложио је тадашњи декан, проф. др Слободан Грубачић. 
Катедра за неохеленске студије је почела је с радом школске 1995/199654, дакле 1. октобра 1995. године. Било је предвиђено да се на Катедру за неохеленске студије упише 25 студената, али је интересовање ${ }^{55}$ било изузетно велико, тако

54 За потребе похрањивања књига у библиотеку, као и одржавања дела наставе и консултација, Катедри је „додељена“ учионица 125, на првом спрату нове зграде. Дуго година (све до 2010) ова учионица представљаће библиотеку Катедре, лекторску собу, секретаријат Катедре, али и учионицу са 32 места. Од 2010. године Секретаријат Катедре преселиће се на 5. спрат нове зграде, у кабинет 514, а средствима из донације Републике Кипар учионица 125 ће бити реновирана и у њу ће бити стављен нови намештај, намењен пре свега одлагању писмених задатака студената. Наставни кадар ће добити нове рачунаре, столове и столице, а у њој ће се убудуће одржавати само консултативна настава. Треба нагласити да је простор који је „додељен“ Катедри мали, имајући у виду тренутан број наставника, сарадника и страних лектора, који на њој обављају своје професионалне дужности.

55 Интересовање за студије модерног грчког језика одувек је било веома велико, а број кандидата који су конкурисали за упис у прву годину основних академских студија био је увек вишеструко већи, у односу на број слободних места који сваке године утврђује Влада Републике Србије, на основу предлога Универзитета у Београду, односно Филолошког факултета. За период од академске 1995/1996. године, када је уписана прва генерација студената неохеленистике, па до академске 2003/2004. године нема писаних података о броју кандидата који су конкурисали за упис на студије грчког језика и књижевности. Оно што се поуздано зна јесте да је у академској 1999/2000. години уписано више од 100 студената у прву годину основних академских студија, с обзиром на то да те године, имајући у виду ситуацију у којој се држава нашла након бомбардовања, није био организован квалификациони испит ни на једном универзитету у земљи. За потребе презентовања

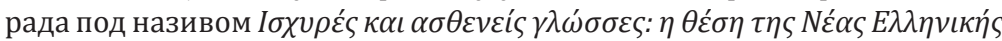

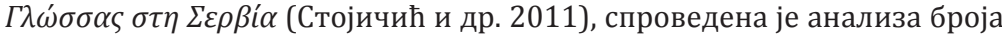
свих кандидата који су конкурисали за упис у прву годину основних академских студија на некој од страних филологија на Филолошком факултету БУ. Тако добијени коефицијенти (за сваку студијску групу у периоду од осам година) показују разлику између квоте (броја понуђених места) и броја пријављених кандидата на испиту за проверу склоности и способности у јуну месецу. Статистички подаци су показали да је интересовање за студије неохеленистике веома велико, с обзиром на то да је у односу на број пријављених и број примљених кандидата, Катедра за неохеленске студије била међу првима по интересовању. Разлоге у оваквом стању ствари можемо пронаћи у неколико чиње- 
да су уписана 42 студента. Сем ових четворогодишњих студија, грчки се могао учити и као изборни четворосеместрални изборни предмет ${ }^{56}$. Како је број студената растао из године у годину, појавила се потреба за ангажовањем већег броја наставника. Поред Филолошког факултета Универзитета у Београду, настава модерног грчког као страног организује се и на Филозофском факултету Универзитета у Београду, на Филозофском факултету Универзитета у Нишу и на Филозофском факултету Универзитета у Новом Саду.

\section{6. Закључак}

Однос суседних језика или језика у контакту обично јесте и лингвистичко и геополитичко питање, тако да то важи и за везе грчког и српског језика, без обзира што немају (више) заједничку границу, а нарочито ако се има у виду садашња геополитичка позиција балканских језика, која се посредно одражава и на политику учења страних језика као једног од стратешких питања међудржавних односа. Иако се образовна

ница. Прво, близина Грчке, традиционално добре културне везе између Србије и Грчке, као и све веће присуство великог броја грчких компанија и предузећа, сигурно су били фактори који су утицали да се кандидати одлуче за студирање грчког језика. Овде напомињемо да кандидати који уписују студије неохеленистике у највећем броју не познају модерни грчки језик, с обзиром на то да грчки језик није предмет из ког се одвија настава у обавезном систему основног или средњег образовања у РС (треба нагласити да постоји неколико пилот пројеката за учење грчког; у неколико школа у Новом Саду се последњих пет година одржава факултативна настава модерног грчког, пре свега захваљујући ангажовању Амбасаде Републике Грчке у Србији, односно надлежног Министарства просвете Републике Грчке; часови модерног грчког који се одржавају спорадично и у Филолошкој гимназији у Београ-

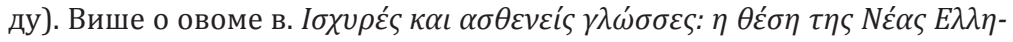

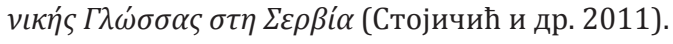

56 Више о организацији наставе обавезних и обавезних по избору предмета, избору дидактичких материјала и резултатима „екстерних евалуација“ студената неохеленистике у периоду од 1995. до 2009. в. у Стојичић и др. 2011; Стојичић 2011; Стојичић 2010. 
Војкан Стојичић / Милена Јовановић

политика у начелу заснива на Повељи о основним правима у ЕУ, она првенствено има национални интерес у виду. То се у случају грчког језика сложило не само у (гео)политичком смислу него и по конкретним интересовањима оних који желе да науче грчки језик и сходно томе по њиховим високим постигнућима, објективно евалуираних. Модерни грчки језик говори релативно мали број људи, што се обично објашњава дигло-

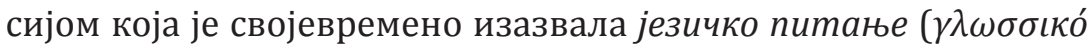
$\zeta \eta ́ \tau \eta \mu \alpha)$ у 19. веку (а коначно се решило тек 1976. године). Реч је о политичкој кризи, изазваној наметањем катаревусе, која је традиционалистички сматрана језиком „вишег“ реда, језиком којим су говорили стари Грци, дакле „супериорна“ и једино прихватљива у институцијама као службени језик школе, цркве и администрације; дотле је димотика, као говорни идиом „простог народа“ и стога „инфериорна“, била обележена, зависно од територије, дијалекатским и другим језичким особеностима, и зато прихватљива (само) за свакодневну употребу. Таква снажна противуречност учинила је да се модерни грчки најчешће, некако успут, изучавао углавном на катедрама за класичну филологију, тако да су најчешће класични филолози, схватајући изванредни значај једног језика чија се еволуција може документовано пратити тридесет векова оснивали катедре за неохеленистику у Европи и шире.

Шездесетих година прошлог века расте интересовање за изучавање модерног грчког језика, тако да све већи број страних студената долази у Грчку ради студија и због тога расте потреба за организовањем наставе/ учења грчког језика као страног. Најпознатије школе за новогрчки језик су у Тесалоники и у Атини, али не треба умањити значај ни других школа (у Грчкој и на Кипру).

У Србији се модерни грчки језик учи на универзитетском нивоу од 1995, када је основана Катедра за неохеленске студије на Филолошком факултету Универзитета у Београду (четворогодишње студије, које су 2006. реформисане у складу са Болоњским процесом). Поред Филолошког факултета Универзитета у Београду, настава модерног грчког као стра- 
ног организује се и на Филозофском факултету Универзитета у Београду, на Филозофском факултету Универзитета у Нишу, и на Филозофском факултету Универзитета у Новом Саду.

Пре тога су Срби у школама учили (класични) грчки језик спорадично, у 18. и у првој половини 19. века, а од тада редовно, као класични језик са латинским, у складу са традиционалним европским образовним моделима. Осим ових традиционалних, тада јединих високих српских школа, постојале су у Србији и грчке школе, које су Грци отварали за своје потребе, а у које су могла ићи и српска деца. Грчки су, међутим, знали и они Срби који су имали трговачке и друге везе са Грцима.

Овај рад, као кратак преглед, представља оквир неопходан за боље разумевање наставе и учења грчког језика. Треба при том истаћи велики значај подршке коју Република Грчка годинама пружа ширењу грчког језика и културе. Али, објективности ради, треба рећи да, ма колико Грци безрезервно подржавали учење свог језика као страног, у чему имају подршку свих надлежних институција у Грчкој, нема реципроцитета у смислу универзитетског учења макар оних језика, чији говорници предњаче у знању грчког. Наиме, за разлику од Филолошког факултета БУ, на коме се изучавају готово сви балкански језици, у универзитетским центрима у Републици Грчкој балкански језици се ретко и спорадично изучавају, укључујући ту и српски језик.

\section{ЛИТЕРАТУРА}

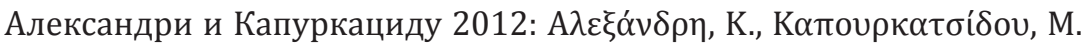

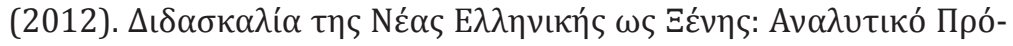

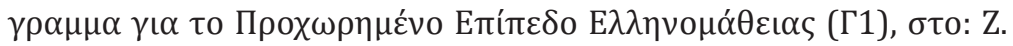
Gavriilidou, A. Efthymiou, E. Thomadaki, P. Kambakis-Vougiouklis (eds.), Selected Papers of The 10th International Conference of Greek

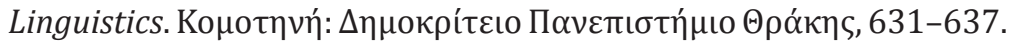

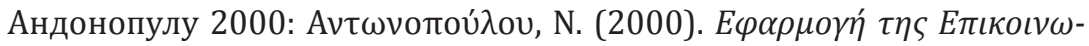

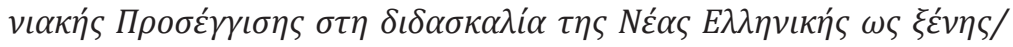

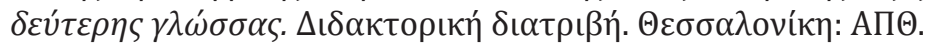


Војкан Стојичић / Милена Јовановић

Јовановић 2011: Јовановић, М. (2011). Из Хермесове палестре. Прилог историји класичке филологије код Срба. Београд: Филолошки факултет. Веб: (31.10.2016)

Јовановић 2012: Jovanović, M. (2012). Klasični grčki jezik u savremenoj visokoškolskoj nastavi, in: A. Akbarov, V. Cook (eds.), Approaches and Methods in Second and Foreign Language Teaching, Sarajevo: IBU Publications, 379-388.

Јовановић 2014: Јовановић, М. (2014). Неохеленске студије и „језичко nитање". Београд: Филолошки факултет, Чигоја штампа. Веб: http://neohelenistika.com/pdf/jovanovic_neohelenske_studije_ i_ jezicko_pitanje.pdf (31.10.2016)

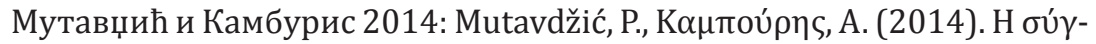

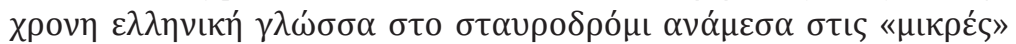

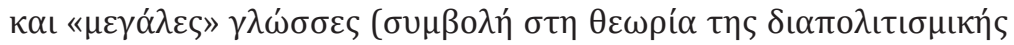

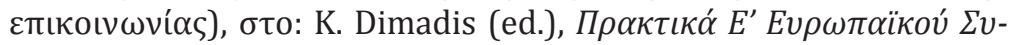

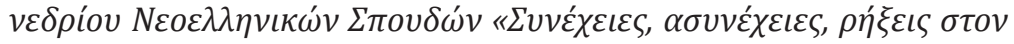

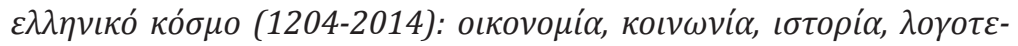
$\chi v i ́ \alpha », \mathrm{~A} \theta \dot{v} v \alpha$ : EEN $\Sigma, 509-526$.

Мутавџић и Стојичић 2013: Мутавџић, П., Стојичић, В. (2013). Савремени балкански језици на почетку новог миленијума, у: C. Гудурић (ур.), Језици и културе у времену и простору I, Нови Сад: Филозофски факултет, 673-679.

Ристовић 2011: Ристовић, Н. (2011). Грчки језик и књижевност у нововековној српској просвети и култури до Вукашина Радишића, у: Н. Тасић (ур.), Почеци наставе грчког језика код Срба, Крагујевац: Лицеум, 11-33.

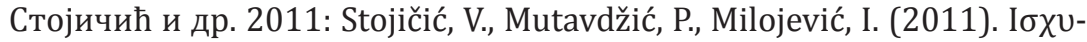

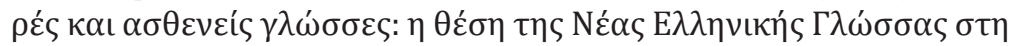

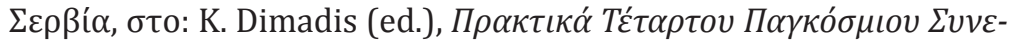

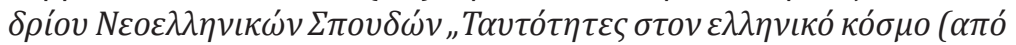

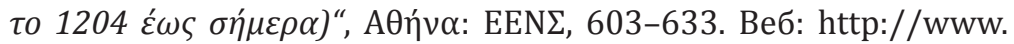
eens.org/EENS_congresses/2010/Identities\%20in\%20the $\% 20$ Greek\%20world\%202010.pdf (31.10.2016)

Ћоровић 2004: Ћоровић, В. (2004). Историја Срба. Земун: ПубликПрактикум. 


\section{Vojkan Stojičić \\ Milena Jovanović}

\section{HELLENIC STUDIES TODAY - CONTRIBUTION TO THE HISTORY OF GREEK LANGUAGE LEARNING}

\section{Summary}

Modern Greek language is spoken by a relatively small number of people. The root of this is usually explained by the effects of the so-called

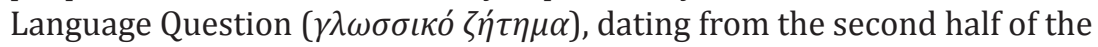
$19^{\text {th }}$ and the beginning of $20^{\text {th }}$ century. The Greek Language Question originated from a dispute on whether the common Greek language ( $\delta \eta \mu \tau \iota \kappa \eta$ ) or a rarified "imitation" of Classical Greek (katharevousa) should be proclaimed as the official language of the Greek nation. The question was ultimately resolved in 1976, when Demotic was chosen. During the early 60's, an increasing number of foreign students was studying in Greece, which in turn demanded a systematic solution for learning Greek as a foreign language. The best known schools were in Thessaloniki and Athens, but other schools had considerable influence as well, both in Greece and on Cyprus. During the second half of the $20^{\text {th }}$ century, Greek as a foreign language was mostly taught at university departments of Classical Philology across the world. With regards to Serbia, Modern Greek has been taught on the university level curriculum since 1995, when the Department of Modern Greek Language and Literature was founded at the University of Belgrade. The four- year studies were reformed according to the Bologna Process in 2006.

Key words: Greek language (as foreign), diglossia, teaching, learning, diaspora, Serbia 